\title{
Changes in QuantiFERON ${ }^{\circledR}-T B$ Gold In-Tube results during treatment for tuberculous infection
}

\author{
M. L. Bastos, ${ }^{* \dagger}$ D. Menzies, ${ }^{\ddagger}$ M. T. C. T. Belo, ${ }^{* \dagger \S}$ E. G. Teixeira, ${ }^{* \dagger \S ~ S . ~ T . ~ d e ~ A b r e u, ~, ~ P . ~ R . ~ Z . ~ A n t a s, ~}{ }^{*}$ \\ A. Trajman*t+ \\ * Medical School and Post-Graduate Health Education Program, Gama Filho University, Rio de Janeiro, Rio de Janeiro, \\ †Tuberculosis Scientific League, Rio de Janeiro, Rio de Janeiro, Brazil; ”Respiratory Epidemiology and Clinical Research \\ Unit, Montreal Chest Institute, McGill University, Montreal, Quebec, Canada; §Medical School, Souza Marques \\ Foundation, Rio de Janeiro, Rio de Janeiro, "Paschoal Granato Laboratory, Rio de Janeiro, Rio de Janeiro, "Clinical \\ Immunology Laboratory, Oswaldo Cruz Institute, Fiocruz, Rio de Janeiro, Rio de Janeiro, Brazil
}

S U M M ARY

SETTING: Randomised trial comparing 9 months of isoniazid with 4 months of rifampicin for the treatment of high-risk tuberculin skin test positive subjects in Rio de Janeiro, Brazil.

OBJeCtIVES: To compare QuantiFERON ${ }^{\circledR}$-TB Gold InTube (QFT-GIT) responses before and 1, 4 and 9 months after starting treatment for latent tuberculous infection (LTBI) according to adherence to one of the two regimens.

DESIGN: Participants in the trial were invited to undergo serial QFT-GIT. Within-subject differences at different time points were analysed as quantitative responses and categorised as positive or negative using different cut-off points.

RESULTS: Of 215 participants, 118 completed treat- ment, of whom 58 underwent all three tests; and 97 did not complete treatment, of whom 10 underwent all tests. After 1 month of treatment, there was no significant difference in QFT-GIT response between the groups. After 4 and 9 months, reversions were more frequent in nonadherent subjects. Marked within-subject fluctuations were observed. No cut-off point could be established at which QFT-GIT responses were consistently positive or associated with adherence or type of treatment.

CONCLUSION: Frequent within-subject variability in QFT-GIT responses, not associated with LTBI treatment, makes it difficult for clinicians to interpret QFT-GIT conversions and reversions.

KEY WORDS: biomarker; interferon-gamma assay; serial testing; latent tuberculosis
INTERFERON-GAMMA (IFN- $\gamma$ ) release assays are increasingly used for the diagnosis of latent tuberculous infection (LTBI). ${ }^{1}$ IFN- $\gamma$ release assays (IGRAs) have operational characteristics that should be ideal for serial testing: they require only a single visit to give a sample, should be free from observer bias in reading results and provide quantitative results with a single manufacturer-defined cut-off point for a positive test. Unlike the tuberculin skin test (TST), they are ex vivo tests; there is thus no antigen administered to sensitise individuals and affect subsequent tests through boosting of anamnestic responses.

However, several studies have reported unexplained variability in IGRA tests, with high rates of reversions and conversions on serial testing. ${ }^{2-7}$ Some variability of IGRA response may reflect differences in time between blood collection and incubation in the lots of the commercialised kits or in the laboratories where tests were performed.6,8-10 IFN- $\gamma$ responses can decline, ${ }^{11-16}$ increase or remain stable ${ }^{17-23}$ after treatment for LTBI and active TB. IGRA reversions are more frequent when initial results are just above the manufacturer's suggested threshold or if a concomitantly performed TST is negative. ${ }^{2-6,11}$ The rate of IGRA conversions has been shown to depend on the definitions used for conversion. ${ }^{3-6,24}$ Authors of these studies have suggested that, as for the TST, the ideal IGRA cut-off point value might vary depending on the clinical situation. ${ }^{2-6,24}$

In contrast to early biomarkers of successful antituberculosis treatment, such as 2-month sputum conversion, ${ }^{25-27}$ there are no validated biomarkers of successful LTBI treatment. ${ }^{28}$ Such biomarkers would be very useful for individual treatment, and would also facilitate trials of alternative LTBI regimens, which at present require lengthy follow-up of large numbers of treated persons, as progression to TB is the only measure of effectiveness.

The aim of the present study was to analyse the effect of LTBI treatment on early and late responses to

Correspondence to: Anete Trajman, Medical School and Health Education, Gama Filho University, Rua Macedo Sobrinho 74/203, Humaitá 22271-080, Rio de Janeiro, Rio de Janeiro, Brazil. Fax: (+552) 12539 9194. e-mail: atrajman@ gmail.com

Article submitted 4 December 2012. Final version accepted 21 February 2013. 
the QuantiFERON® ${ }^{\circledR}$ Gold In-Tube test (QFT-GIT, Cellestis Ltd, Carnegie, VIC, Australia), one of two commercially available IGRAs, and to test different cut-off points that could result in less spontaneous conversions and reversions.

\section{MATERIAL AND METHODS}

\section{Study subjects}

Between August 2010 and June 2012, participants in an international multicentre clinical trial comparing the effectiveness of 9 months of isoniazid (9INH) with 4 months of rifampicin (4RMP) for the treatment of LTBI (http://www.clinicaltrials.govNCT00931736) at the Hospital Geral da Santa Casa de Misericórdia do Rio de Janeiro (HGSCM), Rio de Janeiro, RJ, Brazil, were invited to participate. According to Brazilian National Guidelines, ${ }^{29}$ subjects were eligible for the parent LTBI treatment trial if they had a positive TST $(\geqslant 5 \mathrm{~mm})$ and at least one risk factor for progression to disease, such as immunosuppression, recent conversion or close contact with a person with active infectious TB, regardless of QFT-GIT results.

The study was approved by the Brazilian National Ethical Committee (\#572/09); those who agreed to participate in the present study gave specific signed informed consent in addition to the trial's consent form.

Sociodemographic and clinical information was gathered from the clinical trial's record forms. Adherence to LTBI treatment was defined as taking at least $80 \%$ of prescribed doses each month, and completion of treatment as taking $80 \%$ of doses each month for respectively 4 and 9 months for RMP and INH.

\section{QuantiFERON assays}

Those who agreed to participate underwent a QFTGIT test before treatment $\left(\mathrm{T}_{0}\right)$, and $4\left(\mathrm{~T}_{4}\right)$ and $9\left(\mathrm{~T}_{9}\right)$ months after randomisation, regardless of the type of LTBI treatment or their adherence. Participants included after July 2011 also had a QFT-GIT 1 month $\left(\mathrm{T}_{1}\right)$ after randomisation. Testing was performed at the Central Laboratory, HGSCM, by the same technician, as per the manufacturer's instructions. Briefly, each QFT-GIT consisted of three tubes: 1) a TB antigen tube containing the specific Mycobacterium tuberculosis antigens, 2) a mitogen control tube containing a non-specific T-cell-stimulating antigen and serving as a positive control, and 3) a nil control tube containing no antigens and serving as a negative control. The tubes were inoculated with $1 \mathrm{ml}$ of whole blood after an average of $15 \mathrm{~min}$ resting and were then incubated at $37^{\circ} \mathrm{C}$ for $16-24 \mathrm{~h}$. Enzyme-linked immunosorbent assays for IFN- $\gamma$ were performed manually.

Absorbance was read using an automated instrument. IFN- $\gamma$ levels were recorded and the difference between the TB antigen tube response and the nil tube was used to define QFT-GIT results. Indeterminate results were defined per the manufacturer's instructions: nil tube result $>8$ international units $(\mathrm{IU}) / \mathrm{ml}$ and/or mitogen tube minus nil tube result $<0.5 \mathrm{IU} / \mathrm{ml}$ and $\mathrm{TB}$ antigen tube minus nil tube $<0.35 \mathrm{IU} / \mathrm{ml} .{ }^{30}$

\section{Data analysis}

QFT-GIT responses were analysed quantitatively and qualitatively. For quantitative analyses, the IFN- $\gamma$ responses at different time points and the average monthly change in these responses and between those who adhered and did not adhere to treatment were compared. Monthly change was calculated by dividing the observed change by the number of months between time points. For comparisons between $\mathrm{T}_{0}$ and $\mathrm{T}_{4}$ or $\mathrm{T}_{9}$, three categories were used: negative $(<0.35 \mathrm{IU} / \mathrm{ml})$, borderline $(0.35-0.99 \mathrm{IU} / \mathrm{ml})$ and strongly positive $(>1 \mathrm{IU} / \mathrm{ml})$.

To evaluate factors associated with conversion and reversion (age, sex, history of contact with active $\mathrm{TB}$, immunosuppression, pre-treatment QFT-GIT result, TST, type of treatment), IFN- $\gamma$ results from three time points $\left(T_{0}, T_{4}\right.$ and $\left.T_{9}\right)$, were dichotomised (positive/negative) in 1) $>$ and $<0.35 \mathrm{IU} / \mathrm{ml}$ (the manufacturer's suggested threshold) and 2) $>$ and $<1 \mathrm{IU} / \mathrm{ml}$.

Previous studies have proposed 'borderline zones' (or uncertainty zones) ranging from 0.10 to $0.80 \mathrm{IU} / \mathrm{ml}$ to address variability and stable results. $3,6,7,9,10,24,31-33$ As there is no consensus, to explore potential cut-off points that might be associated with more stable QFT-GIT results, the IFN- $\gamma$ responses in our study were also categorised into the following arbitrarily defined groups: 1) $0.0-0.34 \mathrm{IU} / \mathrm{ml}, 2$ ) $0.35-0.7 \mathrm{IU} / \mathrm{ml}$, 3) $0.7-1.0 \mathrm{IU} / \mathrm{ml}, 4) 1.0-2.0 \mathrm{IU} / \mathrm{ml}$, and 5$) \geqslant 2 \mathrm{IU} / \mathrm{ml}$. Using these categories, conversions were defined as any increase in category, and reversions as any decrease in category. If results increased, then decreased (or vice versa), the first change was used to analyse characteristics associated with change. Stable results were defined as no change in category observed with all test results.

Median changes in IFN- $\gamma$ values from different time point results were compared among adherent and non-adherent subjects using the Wilcoxon nonparametric test. Proportions of conversions and reversions as well as associations were compared using Fisher's exact test. All statistical analyses were performed using SAS, version 9.2 (SAS Institute, Cary, NC, USA).

\section{RESULTS}

\section{Description of study participants}

All of the 215 participants in the parent trial agreed to participate in the QFT-GIT study; 55 (26\%) were excluded from all subsequent analyses as they provided 


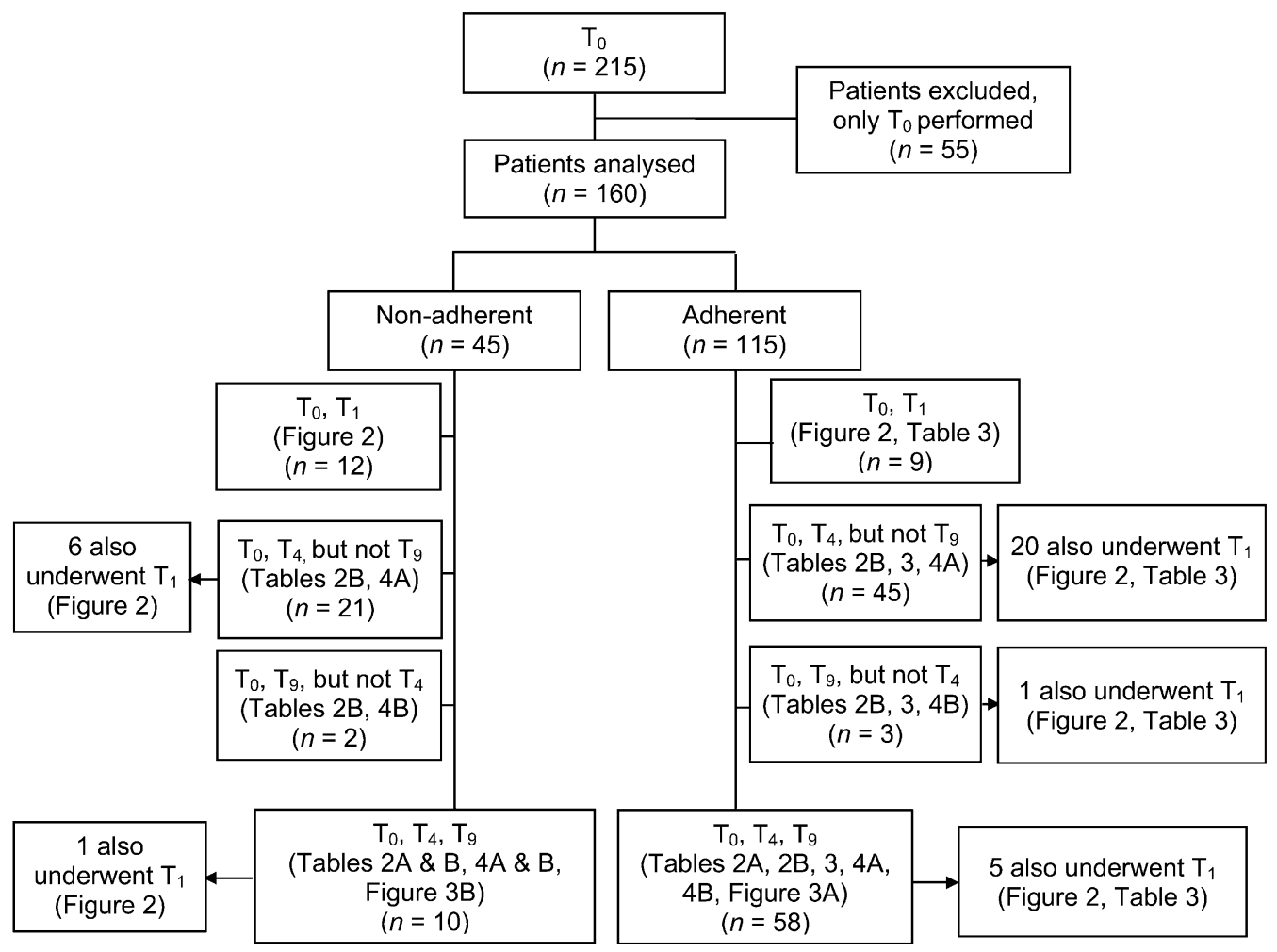

Figure 1 Flow chart of study participants by adherence status and number of tests performed. QFT-GIT = QuantiFERON ${ }^{\circledR}$ TB Gold In-Tube; $T_{0}=$ QFT-GIT before treatment start; $\mathrm{T}_{1}, \mathrm{~T}_{4}, \mathrm{~T}_{9}=$ QFT-GIT at 1, 4 and 9 months of follow-up, respectively.

Table 1 Demographic and clinical characteristics of study participants

\begin{tabular}{|c|c|c|c|c|c|c|}
\hline Variable & $\begin{array}{l}\text { Adherent* } \\
\text { and underwent } \\
\text { all three tests } \\
\left(\mathrm{T}_{0}, \mathrm{~T}_{4}, \mathrm{~T}_{9}\right) \\
(n=58) \\
n(\%)\end{array}$ & $\begin{array}{l}\text { Non-adherent } \\
\text { and underwent } \\
\text { all three tests } \\
\left(T_{0}, T_{4}, T_{9}\right) \\
(n=10) \\
n(\%)\end{array}$ & $P$ value & $\begin{array}{l}\text { Adherent* } \\
\text { and underwent } \\
\text { at least one } \\
\text { serial test } \\
(n=57) \\
n(\%)\end{array}$ & $\begin{array}{l}\text { Non-adherent } \\
\text { and underwent } \\
\text { at least one } \\
\text { serial test } \\
(n=35) \\
n(\%)\end{array}$ & $P$ value \\
\hline Age, years, median [IQR] & $43.5[33-50]$ & $37.5[29-42]$ & 0.048 & $45[35-51]$ & 35 [25-49] & 0.044 \\
\hline $\begin{array}{l}\text { Sex } \\
\text { Female } \\
\text { Male }\end{array}$ & $\begin{array}{l}27(47) \\
31(53)\end{array}$ & $\begin{array}{l}6(60) \\
4(40)\end{array}$ & 0.506 & $\begin{array}{l}28(49) \\
29(51)\end{array}$ & $\begin{array}{l}17(49) \\
18(51)\end{array}$ & 1.0 \\
\hline $\begin{array}{l}\text { TST, mm } \\
\quad 5-9 \\
10-14 \\
\geqslant 15\end{array}$ & $\begin{array}{l}19(33) \\
22(38) \\
17(29)\end{array}$ & $\begin{array}{l}2(20) \\
3(30) \\
5(50)\end{array}$ & 0.473 & $\begin{array}{l}15(26) \\
20(35) \\
22(39)\end{array}$ & $\begin{array}{r}8(23) \\
14(40) \\
13(37)\end{array}$ & 0.891 \\
\hline $\begin{array}{l}\text { Indication for LTBI treatment } \\
\text { Contact } \\
\text { Immunosuppression }\end{array}$ & $\begin{array}{l}38(66) \\
20(34)\end{array}$ & $\begin{array}{l}7(70) \\
3(30)\end{array}$ & 1.0 & $\begin{array}{l}26(46) \\
31(54)\end{array}$ & $\begin{array}{r}27(77) \\
8(23)\end{array}$ & 0.004 \\
\hline $\begin{array}{l}\text { History of BCG vaccination } \\
\text { Yes } \\
\text { No } \\
\text { Unknown }\end{array}$ & $\begin{array}{l}53(91) \\
3(5) \\
2(3)\end{array}$ & $\begin{array}{l}9(90) \\
0 \\
1(10)\end{array}$ & 0.630 & $\begin{array}{l}54(95) \\
3(5) \\
0\end{array}$ & $\begin{array}{l}34(97) \\
1(3) \\
0\end{array}$ & 1.0 \\
\hline $\begin{array}{l}\text { Smoking } \\
\text { Never } \\
\text { Current } \\
\text { Ex-smoker }\end{array}$ & $\begin{array}{l}34(59) \\
11(19) \\
13(22)\end{array}$ & $\begin{array}{l}8(80) \\
1(10) \\
1(10)\end{array}$ & 0.555 & $\begin{array}{l}24(42) \\
13(23) \\
20(35)\end{array}$ & $\begin{array}{r}24(72) \\
5(14) \\
5(14)\end{array}$ & 0.021 \\
\hline $\begin{array}{l}\text { Treatment regimen } \\
4 \text { months of RMP } \\
9 \text { months of INH }\end{array}$ & $\begin{array}{l}26(45) \\
32(55)\end{array}$ & $\begin{array}{l}6(60) \\
4(40)\end{array}$ & 0.498 & $\begin{array}{l}38(67) \\
19(33)\end{array}$ & $\begin{array}{r}8(23) \\
27(77)\end{array}$ & $<0.001$ \\
\hline $\begin{array}{l}\text { Pre-treatment QFT-GIT } \\
\quad<0.35 \mathrm{IU} / \mathrm{ml} \text { (negative) } \\
0.35-1 \mathrm{IU} / \mathrm{ml} \text { (borderline) } \\
\geqslant 1 \mathrm{IU} / \mathrm{ml} \text { (strongly positive) }\end{array}$ & $\begin{array}{l}18(31) \\
10(17) \\
30(52)\end{array}$ & $\begin{array}{l}1(10) \\
1(10) \\
8(80)\end{array}$ & 0.294 & $\begin{array}{l}22(39) \\
11(19) \\
24(42)\end{array}$ & $\begin{array}{r}15(43) \\
5(14) \\
15(43)\end{array}$ & 0.849 \\
\hline
\end{tabular}

* Subjects were considered adherent when they took at least $80 \%$ of total prescribed doses.

$\mathrm{T}_{0}=$ QFT-GIT test before treatment; $\mathrm{T}_{4}=$ QFT-GIT test at 4 months; $\mathrm{T}_{9}=$ QFT-GIT test at 9 months; IQR = interquartile range; TST = tuberculin skin test; LTBI = latent tuberculous infection; BCG = bacille Calmette-Guérin; RMP = rifampicin; INH = isoniazid; QFT-GIT = QuantiFERON ${ }^{\circledR}-$ TB Gold In-Tube. 
only pre-treatment QFT-GIT samples. The median age was 28 years (interquartile range [IQR] 24-40), $58 \%$ were female, and $52(95 \%)$ were non-adherent to treatment. The median dose intake among excluded non-adherent subjects was 0 (IQR 0-27). A summary of the 160 participants and availability of their test results in both the adherent $(n=115,72 \%)$ and non-adherent $(n=45)$ groups is given in Figure 1.

The median dose intake among the non-adherent participants was 30 (IQR 0-84). The characteristics of the treatment adherent and non-adherent participants who adhered and who did not adhere to the serial QFT-GIT protocol are compared in Table 1.

\section{Quantitative changes in IGRA results}

The QFT-GIT results 1 month after randomisation had not changed in most subjects, and any changes seen were not associated with treatment adherence (Figure 2) up to that point. The quantitative QFT-GIT responses declined over time after the first month, but this decline was not associated with treatment adherence (Table 2A and B, Figure 3A and B) nor type of treatment (Table 3 ). The median monthly drop in IFN- $\gamma$ levels was $0.04 \mathrm{IU} / \mathrm{ml}$ among adherent and $0.13 \mathrm{IU} / \mathrm{ml}$ among non-adherent subjects (Table 2A and B), although the difference between the two groups was only significant for the change between months

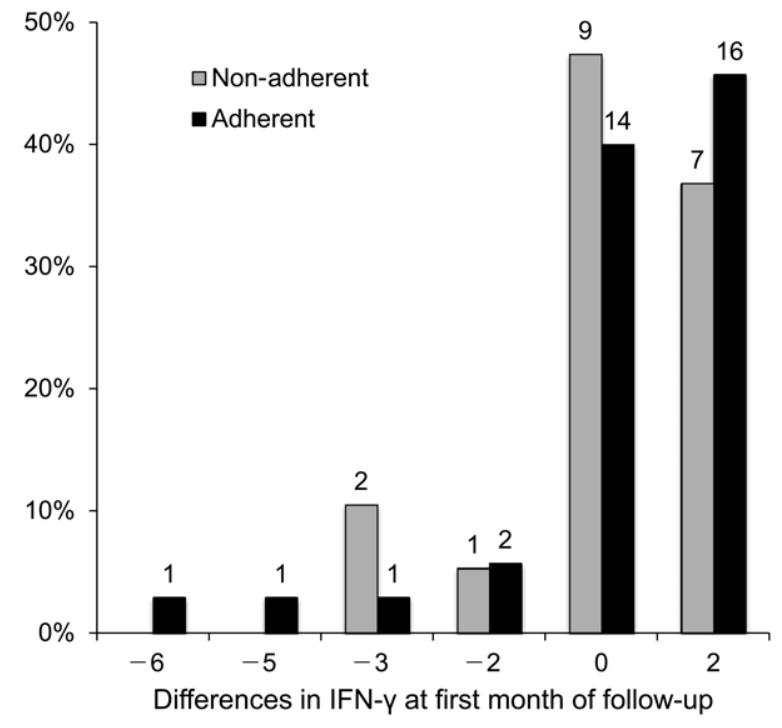

Figure 2 Differences in IFN- $\gamma$ levels after 1 month of enrolment comparing 35 adherent and 19 non-adherent subjects; no changes were associated with adherence status $(P=0.556)$. IFN- $\gamma=$ interferon-gamma.

4 to 9. The marked variability in QFT-GIT responses over the three time points and the lack of relationship with LTBI treatment adherence are shown in Figure 3A (adherent) and B (non-adherent).

Table 2 Differences in median values of serial QFT-GIT testing

A 68 subjects (58 adherent and 10 non-adherent) who underwent all three tests $\left(T_{0}, T_{4}, T_{9}\right)$

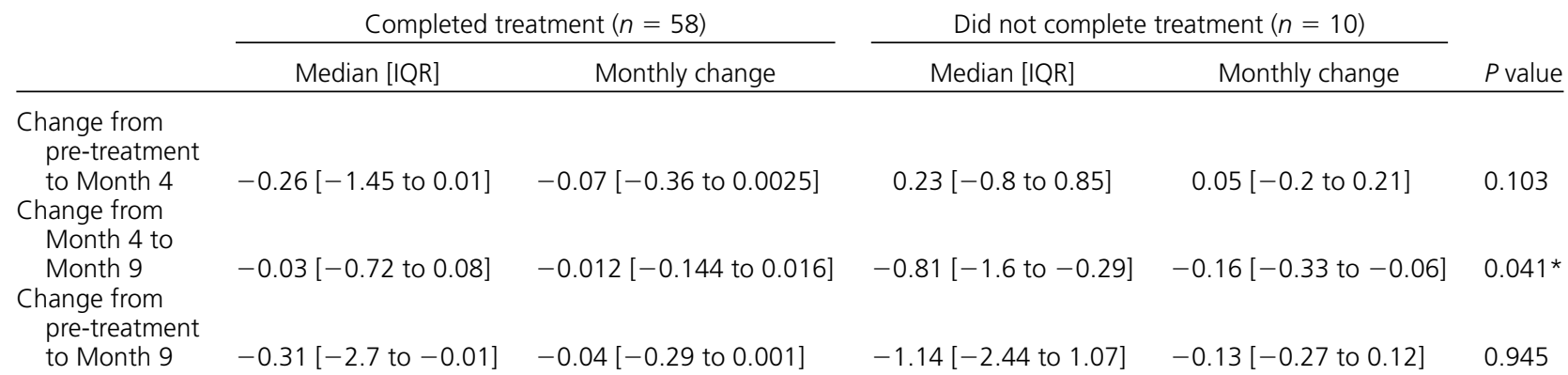

B Those who did not undergo all three tests $\left(T_{0}, T_{4}, T_{9}\right)$

\begin{tabular}{|c|c|c|c|c|c|c|c|}
\hline & \multicolumn{3}{|c|}{ Adherent to treatment up to time of test } & \multicolumn{3}{|c|}{ Non-adherent to treatment up to time of test } & \multirow[b]{2}{*}{$P$ value } \\
\hline & $n$ & Median [IQR] & Monthly change & $n$ & Median [IQR] & Monthly change & \\
\hline $\begin{array}{l}\text { Change from } \\
\text { pre-treatment } \\
\text { to Month } 4^{+}\end{array}$ & 103 & $-0.10[-1.4$ to 0.17$]$ & $-0.03[-0.33$ to & 31 & $0.01[-0$ & 0.0025[ & 0.230 \\
\hline $\begin{array}{l}\text { Change from } \\
\text { Month } 4 \text { to }\end{array}$ & & & & & & & \\
\hline $\begin{array}{l}\text { Month } 9^{\ddagger} \\
\text { Change from } \\
\text { pre-treatment } \\
\text { to Month } 9 \S\end{array}$ & 58 & $-0.06[-0.72$ to 0.08$]$ & $-0.012[-0.14$ to 0.02$]$ & 10 & $-0.82[-1.6$ to -0.29$]$ & $-0.16[-0.33$ to -0.06$]$ & 0.041 * \\
\hline
\end{tabular}

* QFT-GIT response showed significantly greater decrease in non-adherent than in adherent subjects.

†Pre-treatment to Month 4: 58 adherent subjects who underwent all three tests plus 45 who underwent $T_{0}$ and $T_{4}$, and 10 non-adherent subjects who underwent all three tests plus 21 who underwent $T_{0}$ and $T_{4}$.

₹Month 4 to Month 9: 58 treatment-adherent subjects and 10 treatment non-adherent subjects who underwent all three tests.

§Pre-treatment to Month 9: 58 adherent subjects who underwent all tests plus 3 who underwent $T_{0}$ and $T_{9}$, and 10 non-adherent subjects who underwent all tests plus 2 who underwent $T_{0}$ and $T_{9}$.

QFT-GIT = QuantiFERON ${ }^{\circledR}$-TB Gold In-Tube; $\mathrm{T}_{0}=$ QFT-GIT test before treatment; $\mathrm{T}_{4}=$ QFT-GIT test at 4 months; $\mathrm{T}_{9}=$ QFT-GIT test at 9 months; IQR $=$ interquartile range. 

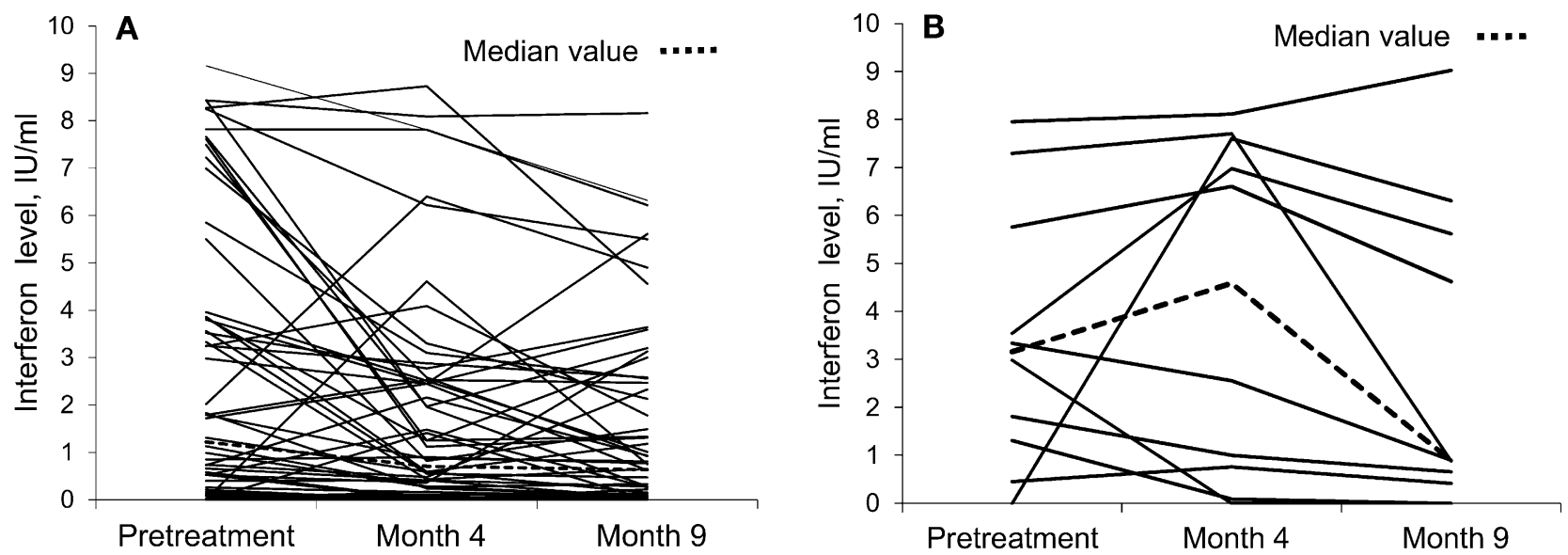

Figure 3 Quantitative QFT-GIT responses over time. Figure shows only subjects who underwent all three tests $\left(T_{0}, T_{4}, T_{9}\right)$ and A) those who completed LTBI treatment $(n=58)$ and B) those who did not complete LTBI treatment $(n=10)$. Marked variability in QFT-GIT responses over the three time points is observed and the lack of association with treatment. IU = international unit; QFT-GIT = QuantiFERON ${ }^{\circledR}$-TB Gold In-Tube; $T_{0}=$ QFT-GIT before treatment start; $T_{1}, T_{4}, T_{9}=$ QFT-GIT at 1, 4 and 9 months of followup, respectively.

Table 3 Differences in median values of serial QFT-GIT test among treatment adherent participants by the regimen

\begin{tabular}{lccccc}
\hline & & 4RMP & 9INH & \\
& $n$ & median [IQR] & $n$ & median [IQR] & $P$ value \\
\hline Change from pre-treatment to Month 1 & 18 & $-0.07[-1.3$ to 0.6$]$ & 17 & $0.02[-0.1$ to 0.57$]$ & 0.121 \\
Change from pre-treatment to Month 4 & 59 & $-0.1[-0.9$ to 0.2$]$ & 44 & $-0.1[-1.4$ to 0.03$]$ & 0.829 \\
Change from Month 4 to Month 9 & 26 & $0.01[-0.37$ to 0.2] & 32 & $-0.07[-0.9$ to 0.01$]$ & 0.244 \\
Change from pre-treatment to Month 9 & 27 & $-0.2[-1.46$ to 0.12] & 34 & $-0.2[-2.8$ to -0.01$]$ & 0.504 \\
\hline
\end{tabular}

QFT-GIT = QuantiFERON ${ }^{\circledR}$-TB Gold In-Tube; RMP = rifampicin; IQR = interquartile range; INH = isoniazid

\section{Qualitative changes: conversions and reversions \\ Comparison of responses pre-treatment and at Month $4\left(T_{0}-T_{4}\right)$}

This analysis included 58 adherent and 10 nonadherent subjects who had completed all three tests $\left(\mathrm{T}_{0}, \mathrm{~T}_{4}\right.$ and $\left.\mathrm{T}_{9}\right)$, plus an additional 45 adherent and 21 non-adherent subjects who had tests pre-treatment and after 4 months $\left(\mathrm{T}_{0}\right.$ and $\left.\mathrm{T}_{4}\right)$. Between pre-treatment and 4 months, $74 \%$ of participants had stable QFTGIT responses (Table 4A). Reversions occurred in $18 \%$ of subjects overall, and conversions in $8 \%$. Both changes were slightly more frequent among adherent subjects, although the difference was not statistically significant $(P=0.7)$.

\section{Comparison of responses pre-treatment and at Month $9\left(T_{0}-T_{9}\right)$}

This analysis included 58 adherent and 10 nonadherent subjects who had completed all three tests $\left(\mathrm{T}_{0}, \mathrm{~T}_{4}\right.$ and $\left.\mathrm{T}_{9}\right)$, plus an additional 3 adherent and 2 non-adherent subjects who had tests pre-treatment and after 9 months $\left(\mathrm{T}_{0}\right.$ and $\left.\mathrm{T}_{9}\right)$. Over the 9 months, $63 \%$ of subjects had stable reactions, $30 \%$ had decreased reactions and conversions were observed in 7\% (Table 4B). Reversions 9 months after randomisation were more frequent in the non-adherent than in the adherent group $(P=0.035)$.
Table 4 Changes in categorised QFT-GIT results compared to pre-treatment by adherence to LTBI treatment

\begin{tabular}{lcccr}
\hline A Changes at 4 months* & & & \\
& $\begin{array}{c}\text { Decrease } \\
n(\%)\end{array}$ & $\begin{array}{c}\text { Stable }^{\dagger} \\
n(\%)\end{array}$ & $\begin{array}{c}\text { Increase } \\
n(\%)\end{array}$ & $\begin{array}{r}\text { Total } \\
n(\%)\end{array}$ \\
\hline Non-adherent & $4(13)$ & $25(81)$ & $2(6)$ & $31(100)$ \\
Adherent & $20(19)$ & $74(72)$ & $9(9)$ & $103(100)$ \\
$\quad$ Total & $24(18)$ & $99(74)$ & $11(8)$ & $134(100)$
\end{tabular}

B Changes at 9 months ${ }^{\ddagger}$

\begin{tabular}{lcccc} 
& $\begin{array}{c}\text { Decrease }^{\dagger} \\
n(\%)\end{array}$ & $\begin{array}{c}\text { Stable }^{\dagger} \\
n(\%)\end{array}$ & $\begin{array}{c}\text { Increase }^{\dagger} \\
n(\%)\end{array}$ & $\begin{array}{c}\text { Total } \\
n(\%)\end{array}$ \\
\hline Non-adherent & $6(50)$ & $4(33)$ & $2(17)$ & $12(100)$ \\
Adherent & $16(26)$ & $42(69)$ & $3(5)$ & $61(100)$ \\
$\quad$ Total & $22(30)$ & $46(63)$ & $5(7)$ & $73(100)$
\end{tabular}

*Analysis of 58 subjects adherent and 10 non-adherent to all three tests, and 45 subjects adherent and 21 non-adherent to tests at $T_{0}$ and $\mathrm{T}_{4}$. Fisher's exact test to compare non-adherent and adherent subjects, $P=0.7$.

+Decrease: from strongly positive $(>1 \mathrm{IU} / \mathrm{ml})$ to borderline $(0.35-1 \mathrm{IU} / \mathrm{ml})$ or from borderline $(0.35-1 \mathrm{IU} / \mathrm{ml})$ to negative or from strongly positive $(>1 \mathrm{IU} / \mathrm{ml})$ to negative $(<0.35 \mathrm{IU} / \mathrm{ml})$; Stable: individuals who remain in the same category; Increase: from negative $(<0.35 \mathrm{IU} / \mathrm{ml})$ to borderline $(0.35-1 \mathrm{IU} / \mathrm{ml})$ or from negative $(<0.35 \mathrm{IU} / \mathrm{ml})$ to strongly positive $(>1 \mathrm{IU} / \mathrm{ml})$ or from borderline $(0.35-1 \mathrm{lU} / \mathrm{ml})$ to positive $(>1 \mathrm{lU} / \mathrm{ml})$.

${ }^{\ddagger}$ Analysis of 58 subjects adherent and 10 non-adherent to all three tests, and 5 subjects adherent to tests at $T_{0}$ and $T_{9}$. Fisher's exact test to compare nonadherent and adherent subjects $(P=0.035)$, showing a significant decrease among non-adherent subjects.

QFT-GIT = QuantiFERON ${ }^{\circledR}$-TB Gold In-Tube; LTBI = latent tuberculous infection; $\mathrm{T}_{0}=$ QFT-GIT test before treatment; $\mathrm{T}_{4}=$ QFT-GIT test at 4 months; $\mathrm{T}_{9}=$ QFT-GIT test at 9 months; IU = international unit. 
Comparison of three time points

$\left(T_{0}, T_{4}, T_{9} ; \mathrm{n}=68\right)$

A Cut-off $0.35 \mathrm{IU} / \mathrm{ml}$ to define conversion/ reversion. Using the cut-off suggested by the manufacturer, reactions in $53(78 \%)$ participants were stable, conversions occurred in three $(4 \%)$ and reversions occurred in $12(18 \%)$. The pre-treatment QFT-GIT value was the only variable associated with reversion of QFT-GIT results: subjects with QFT reversions had lower pre-treatment QFT-GIT responses (median IFN- $\gamma$ : $0.8 \mathrm{IU} / \mathrm{ml}$, IQR $0.5-1.2$ ) than in subjects with all tests positive (3.80 IU/ml, IQR 2.0-7.5, $P<0.001$ ).

B Cut-off $1.0 \mathrm{IU} / \mathrm{ml}$ to define conversion/ reversion. Using this higher cut-off point, 46 (66\%) participants were stable, conversions occurred in 6 $(9 \%)$ and reversions in $16(24 \%)$. None of the measured clinical characteristics were significantly associated with reversion or conversion defined using this cut-off.

C Cut-off with five different categories: i) 0.0$0.34 \mathrm{IU} / \mathrm{ml}$; ii) $0.35-0.7 \mathrm{IU} / \mathrm{ml}$; iii) $0.7-1.0 \mathrm{IU} / \mathrm{ml}$; iv) $1.0-2.0 \mathrm{IU} / \mathrm{ml}$ and $v) \geqslant 2 \mathrm{IU} / \mathrm{ml}$. Of the 68 participants analysed, $19(28 \%)$ had negative pretreatment results. Of $30(44 \%)$ subjects with pretreatment results $\geqslant 2 \mathrm{IU} / \mathrm{ml}, 16(24 \%)$ decreased in category, four $(6 \%)$ of whom reverted to $<0.35 \mathrm{IU} / \mathrm{ml}$ and another $12(18 \%)$ reverted to $0.35-0.99 \mathrm{IU} / \mathrm{ml}$. Among $19(28 \%)$ subjects with pre-treatment results between $0.35 \mathrm{IU} / \mathrm{ml}$ and $2 \mathrm{IU} / \mathrm{ml}$, in only one $(1 \%)$ subject were all results in the same category at all three time points. Among the remainder, 12 (18\%) had reversions and seven $(10 \%)$ had conversions.

\section{DISCUSSION}

In the present study, we observed stable categorical QFT-GIT results when the test was repeated three times over 9 months in the majority of subjects starting treatment for LTBI, regardless of treatment completion or type of regimen. In contrast with previous findings, ${ }^{7,34}$ we did not have indeterminate results in any test at any time point. The low adherence to LTBI treatment was consistent with previous findings in the same setting. ${ }^{35}$ However, quantitative responses varied considerably in almost all subjects, and conversions and reversions were frequent. Two findings related to this variability are worthy of comment. First, these changes were not related to completion/ adherence to LTBI treatment, and second, conversion and reversion rates remained high and unexplained, even with different cut-off points for a positive test well above that suggested by the manufacturer.

Could the findings of marked variability have been the result of technical factors, as previously reported? ${ }^{8-10}$ The QFT-GIT samples were collected and processed in the same laboratory by only one technician using the same procedures. This should have re- duced the possibility of variations in technique resulting in the observed variability of results.

A significant decrease in IFN- $\gamma$ levels after LTBI treatment has been reported in two studies, ${ }^{11,15}$ and a sustained positive result was reported in untreated LTBI subjects. ${ }^{36}$ However, other studies have described persistence of positive QFT-GIT results after LTBI treatment. ${ }^{21,23}$ Reversion of IGRAs following treatment may reflect clearance of $M$. tuberculosis infection with treatment, although a long follow-up period after LTBI treatment would be needed to determine if those with reversion really had a very low risk of subsequent disease. In our study, treatment was not associated with decrease in IFN- $\gamma$ levelsanalysed quantitatively or qualitatively, and after 1, 4 and 9 months. This consistent finding suggests that reversion might not be a good marker of LTBI cure nor of decreased risk for progression to active TB. It is possible that reversion simply reflects a high degree of biological variation. ${ }^{2,33}$

Increases in IFN- $\gamma$ levels and conversions were also observed. This might be due to continued exposure to M. tuberculosis in a high-incidence context, but it can also result from variability of the test. It is welldocumented that some variability, inherent to the test, is expected. ${ }^{37}$ Fluctuation can occur due to differences in laboratory technique steps, such as incubation duration, biological and environmental or non-

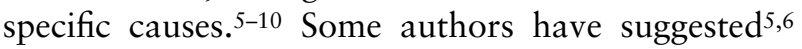
that conversion should not be defined simply as a change from below to above the manufacturer's suggested cut-off point for a positive test, but that it should be defined based on the standard deviation due to biological and technical variability measured in carefully controlled situations, as has been done for the TST.4-6,24 At present, the definition for QFTGIT conversion remains a challenge.

Decreases in specific IFN- $\gamma$ response were slightly more frequent among those with an initial result close to the cut-off point, but were unexpectedly frequent among those with higher initial IFN- $\gamma$ levels, in contrast to several previous studies. ${ }^{3,6,33}$ In this study, a cut-off could therefore not be identified above which reversions and conversions were substantially less frequent.

Our study had some limitations. The sample size was small, particularly in the case of participants who were non-adherent to treatment and who underwent all QFT serial tests. This is expected, as participants who do not adhere to treatment recommendations are unlikely to adhere to blood testing. There are a few differences in participants' pre-testing characteristics that could have biased serial QFT results. However, demographic characteristics such as age, sex and tobacco use were not associated with withinsubject QFT variability in previous studies. ${ }^{16,33,38-40}$ Higher adherence to LTBI treatment with the 4RMP regimen ${ }^{41}$ and by immunosuppressed patients ${ }^{42}$ was 
expected, and could also have influenced the QFT results. As the parent randomised controlled trial was a pragmatic study, it was not possible to control for these variables. However, according to our analyses, neither the type of treatment nor immunosuppression seemed to interfere with variability of QFT results.

Thus, despite the above limitations, we conclude that LTBI treatment appeared to have no effect on the results of serial QFT-GIT testing, which were nevertheless highly variable. No cut-off could be identified that significantly reduced the rates of spontaneous conversions and reversions. Unexplained and frequent variability in QFT-GIT results makes it difficult to interpret conversions and reversions in an individual.

\section{Acknowledgements}

The authors thank R Granato for his kind support with equipment and infrastructure in his laboratory. This study was funded by the Conselho nacional de desenvolvimento científico e tecnológico 558383/2009-2, Canadian Institutes of Health Research (CIHR) MOP 11114967, Fundação Carlos Chagas Filho de Amparo à Pesquisa do Estado do Rio de Janeiro E-26/102.712/2008 and the International Clinical, Operational, and Health Services Research and Training Award 5 U2R TW006883-02 of the National Institutes of Health. AT and PRZA have a PQ-2 research fellowship by $\mathrm{CNPq}$, and MLB has a grant by CNPq, program Science Without Borders (200097/2012-1). Randomised trial of latent tuberculosis infection treatment $(4 \mathrm{v} 9)$ was funded by CIHR.

Conflict of interest: none declared.

\section{References}

1 Denkinger C M, Dheda K, Pai M. Guidelines on interferongamma release assays for tuberculosis infection: concordance, discordance or confusion? Clin Microbiol Infect 2011; 17: 806-814.

2 Hill P C, Brookes R H, Fox A, et al. Longitudinal assessment of an ELISpot test for Mycobacterium tuberculosis infection. PLoS Med 2007; 4: e192.

3 Pai M, Joshi R, Dogra S, et al. Serial testing of health care workers for tuberculosis using interferon-gamma assay. Am J Respir Crit Care Med 2006; 174: 349-355.

4 Pai M, Dheda K, Cunningham J, Scano F, O’Brien R. T-cell assays for the diagnosis of latent tuberculosis infection: moving the research agenda forward. Lancet Infect Dis 2007; 7: 428-438.

5 Pai M, O’Brien R. Serial testing for tuberculosis: can we make sense of T-cell assay conversions and reversions? PLoS Med 2007; 4: e208.

6 Veerapathran A, Joshi R, Goswami K, et al. T-cell assays for tuberculosis infection: deriving cut-offs for conversions using reproducibility data. PLoS ONE 2008; 3: e1850.

7 Metcalfe J Z, Cattamanchi A, McCulloch C E, Lew J D, Ha N P, Graviss E A. Test variability of the Quantiferon-TB Gold In-Tube assay in clinical practice. Am J Respir Crit Care Med 2012; 26: 26.

8 Doberne D, Gaur R L, Banaei N. Preanalytical delay reduces sensitivity of QuantiFERON-TB Gold In-Tube assay for detection of latent tuberculosis infection. J Clin Microbiol 2011; 49: 3061-3064.

9 Detjen A K, Loebenberg L, Grewal H M, et al. Short-term reproducibility of a commercial interferon gamma release assay. Clin Vaccine Immunol 2009; 16: 1170-1175.

10 Whitworth W C, Hamilton L R, Goodwin D J, et al. Withinsubject interlaboratory variability of QuantiFERON-TB Gold In-Tube tests. PLoS ONE 2012; 7: 6.
11 Ewer K, Millington K A, Deeks J J, Alvarez L, Bryant G, Lalvani A. Dynamic antigen-specific T-cell responses after pointsource exposure to Mycobacterium tuberculosis. Am J Respir Crit Care Med 2006; 174: 831-839.

12 Pathan A A, Wilkinson K A, Klenerman P, et al. Direct ex vivo analysis of antigen-specific IFN-gamma-secreting CD4 T-cells in Mycobacterium tuberculosis-infected individuals: associations with clinical disease state and effect of treatment. J Immunol 2001; 167: 5217-5225.

13 Carrara S, Vincenti D, Petrosillo N, Amicosante M, Girardi E, Goletti D. Use of a T-cell-based assay for monitoring efficacy of antituberculosis therapy. Clin Infect Dis 2004; 38: 754756.

14 Kobashi Y, Mouri K, Yagi S, Obase Y, Miyashita N, Oka M. Transitional changes in T-cell responses to Mycobacterium tuberculosis-specific antigens during treatment. J Infect 2009; 58: 197-204.

15 Chee C B, KhinMar K W, Gan S H, Barkham T M, Pushparani $\mathrm{M}$, Wang $\mathrm{Y} \mathrm{T}$. Latent tuberculosis infection treatment and T-cell responses to Mycobacterium tuberculosis-specific antigens. Am J Respir Crit Care Med 2007; 175: 282-287.

16 Komiya K, Ariga H, Nagai H, et al. Reversion rates of QuantiFERON-TB Gold are related to pre-treatment IFN-gamma levels. J Infect 2011; 63: 48-53.

17 Al-Attiyah R, Mustafa A S, Abal A T, Madi N M, Andersen P. Restoration of mycobacterial antigen-induced proliferation and interferon-gamma responses in peripheral blood mononuclear cells of tuberculosis patients upon effective chemotherapy. FEMS Immunol Med Microbiol 2003; 38: 249-256.

18 Ulrichs T, Anding P, Kaufmann S H E, Munk M E. Numbers of IFN- $\gamma$-producing cells against ESAT-6 increase in tuberculosis patients during chemotherapy. Int J Tuberc Lung Dis 2000; 4: $1181-1183$.

19 Stuart R L, Olden D, Johnson P D R, et al. Effect of antituberculosis treatment on the tuberculin interferon- $\gamma$ response in tuberculin skin test (TST) positive health care workers and patients with tuberculosis. Int J Tuberc Lung Dis 2000; 4: 555561.

20 Pai M, Joshi R, Bandyopadhyay M, et al. Sensitivity of a wholeblood interferon-gamma assay among patients with pulmonary tuberculosis and variations in T-cell responses during anti-tuberculosis treatment. Infection 2007; 35: 98-103.

21 Dyrhol-Riise A M, Gran G, Wentzel-Larsen T, Blomberg B, Haanshuus C G, Morkve O. Diagnosis and follow-up of treatment of latent tuberculosis; the utility of the QuantiFERONTB Gold In-Tube assay in outpatients from a tuberculosis lowendemic country. BMC Infect Dis 2010; 10: 57.

22 Higuchi K, Harada N, Mori T. Interferon-gamma responses after isoniazid chemotherapy for latent tuberculosis. Respirology 2008; 13: 468-472.

23 Pai M, Joshi R, Dogra S, et al. Persistently elevated T cell interferon-gamma responses after treatment for latent tuberculosis infection among health care workers in India: a preliminary report. J Occup Med Toxicol 2006; 1: 7.

24 Pai M, Joshi R, Dogra S, et al. T-cell assay conversions and reversions among household contacts of tuberculosis patients in rural India. Int J Tuberc Lung Dis 2009; 13: 84-92.

25 Epstein M D, Schluger N W, Davidow A L, Bonk S, Rom W N, Hanna B. Time to detection of Mycobacterium tuberculosis in sputum culture correlates with outcome in patients receiving treatment for pulmonary tuberculosis. Chest 1998; 113: 379386.

26 Hesseling A C, Walzl G, Enarson D A, et al. Baseline sputum time to detection predicts month two culture conversion and relapse in non-HIV-infected patients. Int J Tuberc Lung Dis 2010; 14: 560-570.

27 Wallis R S, Wang C, Doherty T M, et al. Biomarkers for tuberculosis disease activity, cure, and relapse. Lancet Infect Dis 2010; 10: 68-69. 
28 Wallis R S, Pai M, Menzies D, et al. Biomarkers and diagnostics for tuberculosis: progress, needs, and translation into practice. Lancet 2010; 375: 1920-1937.

29 Programa Nacional de Controle da Tuberculose, Brazil. Manual de Recomendações para o Controle da Tuberculose no Brasil. Brasilia, Brazil: Ministério da Saùde, 2010. http://portal.saude. gov.br/portal/arquivos/pdf/manual_de_recomendacoes_t.pdf Accessed April 2013. [Portuguese]

30 Cellestis. QuantiFERON ${ }^{\circledR}-\mathrm{TB}$ Gold In-Tube package insert. Carnegie, VIC, Australia: Cellestis, 2009. http://www.cellestis. com/IRM/Company/ShowPage.aspx?CPID =1171 Accessed April 2013.

31 Perry S, Sanchez L, Yang S, Agarwal Z, Hurst P, Parsonnet J. Reproducibility of QuantiFERON-TB Gold In-Tube assay. Clin Vaccine Immunol 2008; 15: 425-432.

32 van Zyl-Smit R N, Zwerling A, Dheda K, Pai M. Within-subject variability of interferon-g assay results for tuberculosis and boosting effect of tuberculin skin testing: a systematic review. PLoS ONE 2009; 4: e8517.

33 Park J S, Lee J S, Kim M Y, et al. Monthly follow-ups of interferon-gamma release assays among healthcare workers in contact with TB patients. Chest 2012; 142: 1461-1468.

34 Santin M, Munoz L, Rigau D. Interferon-gamma release assays for the diagnosis of tuberculosis and tuberculosis infection in HIV-infected adults: a systematic review and meta-analysis. PloS ONE 2012; 7: 5.

35 Trajman A, Long R, Zylberberg D, Dion M J, Al-Otaibi B, Menzies D. Factors associated with treatment adherence in a randomised trial of latent tuberculosis infection treatment. Int J Tuberc Lung Dis 2010; 14: 551-559.

36 Wilkinson K A, Kon O M, Newton S M, et al. Effect of treatment of latent tuberculosis infection on the T-cell response to
Mycobacterium tuberculosis antigens. J Infect Dis 2006; 193: 354-359.

37 Cellestis. Validation report QuantiFERON ${ }^{\circledR}-\mathrm{TB}$ Gold In-Tube: reproducibility study. R06Q4-01. Carnegie, VIC, Australia: 2006. http://www.cellestis.com/IRM/Company/ShowPage. aspx/PDFs/1359-10000000/ValidationReportQFTInTube ReproducibilityStudy Accessed May 2013.

38 Shin S S, Gallardo M, Lozada R, et al. Cigarette-smoking intensity and interferon-gamma release assay conversion among persons who inject drugs: a cohort study. Pulm Med 2012; 828106: 10 .

39 Ringshausen F C, Nienhaus A, Schablon A, Schlosser S, Schultze-Werninghaus G, Rohde G. Predictors of persistently positive Mycobacterium tuberculosis-specific interferon-gamma responses in the serial testing of health care workers. BMC Infect Dis 2010; 10: 220.

40 Shah M, DiPietro D, Greenbaum A, et al. Programmatic impact of QuantiFERON-TB Gold In-Tube implementation on latent tuberculosis diagnosis and treatment in a public health clinic. PloS ONE 2012; 7: 7.

41 Menzies D, Long R, Trajman A, et al. Adverse events with 4 months of rifampin therapy or 9 months of isoniazid therapy for latent tuberculosis infection: a randomized trial. Ann Intern Med 2008; 149: 689-697.

42 Bastos M L, Belo M T C, Silva A P, et al. Factors associated with latent tuberculosis therapy completion in Rio de Janeiro, Brazil [Abstract]. 17th Annual Conference of The Union-North American Region, Vancouver, BC, Canada, 28 February-2 March 2013. http://www.bc.lung.ca/association_and_services/ documents/2013TheUnion-NARPreliminaryProgram-FINAL PROGRAM.pdf Accessed May 2013. 
CONTEXTE : Les participants d'un essai randomisé comparant l'isoniazide pendant 9 mois avec la rifampicine pendant 4 mois pour le traitement de sujets à haut risque et à test tuberculinique cutané positif à Rio de Janeiro, Brésil.

OBJECTIFS : Comparer les réponses du QuantiFERON ${ }^{\circledR}$ TB Gold In-Tube (QFT-GIT) avant et 1, 4 et 9 mois après le début d'un traitement de l'infection tuberculeuse latente (LTBI) en fonction de l'adhésion à un des deux traitements pour la LTBI.

SCHÉMA : On a demandé aux participants à l'essai de subir des tests QFT-GIT en série. On a analysé à différents moments les différences entre sujets sous forme de réponses quantitatives et on les a classées comme positives ou négatives en utilisant diverses limites de positivité.

RÉ SULTATS : Sur 215 participants, 118 ont achevé leur traitement, parmi lesquels 58 ont subi tous les tests ; 97 sujets n’ont pas achevé le traitement, parmi lesquels 10 ont subi tous les tests. Après 1 mois de traitement, on n'a pas noté entre eux de différences significatives dans la réponse du QFT-GIT. Après 4 et 9 mois, les négativations ont été plus fréquentes chez les sujets non-adhérents. On a observé des fluctuations marquées chez le même sujet. On n'a pas pu identifier une limite de positivité à laquelle les réponses QFT-GIT étaient régulièrement positives ou en association avec l'adhésion ou le type de traitement.

CONCLUSION: La variabilité fréquente des réponses QFT-GIT chez le même sujet sans association avec le traitement de la LTBI rend difficile aux cliniciens l'interprétation des positivations et des négativations du QFT-GIT.
MARCO DE REFERENCIA: Un estudio aleatorizado en el cual se compara la eficacia de 9 meses con isoniazida y 4 meses con rifampicina en el tratamiento de personas con una prueba cutánea con tuberculina positiva y con un alto riesgo de contraer la tuberculosis en Río de Janeiro, Brasil.

OBJETIVOS: Comparar los resultados de la prueba QuantiFERON ${ }^{\circledR}$-TB Gold En Tubo (QFT-GIT) antes de comenzar el tratamiento de la infección tuberculosa latente (LTBI) y 1, 4 y 9 meses después de haberlo iniciado, en función del cumplimiento terapéutico con uno de los regímenes.

MÉTODOS: Se invitó a los participantes en el estudio a aceptar la práctica seriada de la prueba QFT-GIT. Se analizaron las variaciones intraindividuales de las respuestas cuantitativas en diferentes momentos del tratamiento y se clasificaron las respuestas en positivas o negativas según varios umbrales.
RES U MEN

RESULTADOS: De los 215 participantes, 118 completaron el tratamiento y de ellos 58 realizaron todas las pruebas previstas; 97 pacientes no completaron el tratamiento y de ellos 10 realizaron todas las pruebas. Después de 1 mes de tratamiento, no se observó ninguna diferencia significativa en el resultado de la prueba QFTGIT entre los grupos. Después de 4 y 9 meses, la reversión del resultado fue más frecuente en los pacientes que habían incumplido el tratamiento. Se observaron notables fluctuaciones en los resultados de cada paciente. No se pudo definir un umbral según el cual las respuestas a la prueba fueran constantemente positivas y que se asociaran con el cumplimiento terapéutico o con el tipo de tratamiento.

CONCLUSIÓN: La frecuente variabilidad intraindividual de las respuestas a la prueba QFT-GIT y su falta de correlación con el LTBI dificulta a los médicos la interpretación de las conversiones y las reversiones de la respuesta. 